\title{
Perineal Carriers of Staphylococci
}

\author{
JOHS. BØE,* M.D. ; C. O. SOLBERG,† M.D. ; TH. M. VOGELSANG,
}

Brit. med. F., 1964, 2, 280-281

A vital problem regarding hospital infection is to differentiate between dangerous and non-dangerous carriers.

It is accepted that persons with septic lesions are more "dangerous" than healthy carriers. It is, however, not known when a healthy carrier should be regarded as dangerous or not, although it is reasonable to suspect a "heavy disperser" to be more dangerous than a person shedding only a few staphylococci to his surroundings.

In most of the investigations on healthy staphylococcal carriers only samples from the nose and throat are obtained. The same is true regarding the very few investigations dealing with the quantitative aspects of the problem. The perineum as a potential source and breeding-place of pathogenic staphylococci was first suggested by Hare and Ridley (1958), and was more thoroughly investigated by Ridley (1959). Gillespie et al. (1958) found that $40-50 \%$ of the neonates were perineal carriers of staphylococci. Tulloch et al. (1960) examined the perineum of patients suffering from chronic furunculosis : $15(56 \%)$ of 24 patients were perineal carriers of pathogenic staphylococci. They suggested that this figure was probably higher than in the general population because perineal swabs were at first taken only from patients with boils on the lower part of the body. Recently Hare (1963) has reported a quantitative study of perineal carriers regarding their spread of staphylococci.

The incidence of perineal carriage of staphylococci is not well known. While it is easy enough to obtain large series of nasal samples, it goes without saying that for many reasons it is much more difficult to obtain a great deal of material showing the incidence of perineal carriage. Accordingly, in the investigations previously reported only a few persons have been examined.

We have had the opportunity to examine 3,508 persons for perineal carriage of pathogenic staphylococci as well as nasal and throat carriage. Our findings are reported here.

\section{Material and Methods}

During the period 13 April 1961 to 20 December 1963 3,508 patients admitted to the Medical Department B were examined. There was no selection of the patients, but occasionally samples were not obtained from those who were seriously ill (patients admitted dying from coronary infarction and so on).

The patients were examined within an hour after they had had a bath in the department of admittance. Emergencies admitted during the night and taken direct to their rooms were examined next morning.

The samples were obtained by the same two examiners throughout the period. Nasal and perineal samples were obtained by cotton-wool swabs moistened in saline. Dry swabs were used for throat cultures. It was strongly stressed that the swabs should be firmly rubbed over the perineal region without

\footnotetext{
- Professor of Medicine, University of Bergen, School of Medicine, Medical Department B.

t Research Fellow, University of Bergen, School of Medicine, Medical Department B.

$¥$ Professor of Microbiology, University of Bergen, School of Medicine, The Gade Institute, Department of Microbiology.

5 State Epidemiologist of Western Norway, University of Bergen, School of Medicine, The Gade Institute, Department of Microbiology.
}

touching the anal or vaginal region. They were immediately brought to the microbiological department and plated on phenol-red mannitol salt agar. The swabs were then inoculated into broth which was incubated for 24 hours at $37^{\circ} \mathrm{C}$. A loopful was transferred to mannitol salt agar and incubated for another 48 hours at $37^{\circ} \mathrm{C}$. Staphylococcal colonies were transferred to other media for further examination. The capacity to coagulate rabbit plasma was used as the only criterion for the selection of pathogenic staphylococci. Phagetyping was carried out by the same technique as previously described (Hofstad and Vogelsang, 1960).

\section{Results}

Of 3,508 persons $48 \%$ had pathogenic staphylococci in one or more of the three sites examined, whereas $52 \%$ were negative. Altogether $13 \%$ were positive in the perineum, $34 \%$ in the nose, and $31 \%$ in the throat.

The frequency of staphylococci isolated from single and multiple sites is illustrated in Table I. Perineal carriage was relatively seldom an isolated phenomenon-occurring in only $2.6 \%$ in this series. Most often it was combined with nasal $(3.2 \%)$ or throat carriage $(1.4 \%)$ or both nasal and throat carriage $(5.7 \%)$.

TABLE I.-Frequency of Coagulase-positive Staphylococci Isolated from Nose, Throat, and Perinsum of 3,508 Patients

\begin{tabular}{|c|c|c|c|c|c|c|c|c|}
\hline \multirow{2}{*}{\multicolumn{7}{|c|}{ Cultures }} & \multicolumn{2}{|c|}{ Patients } \\
\hline & & & & & & & \multirow[b]{2}{*}{$\begin{array}{r}\text { No. } \\
1,818 \\
412 \\
362 \\
90 \\
467 \\
111 \\
48 \\
200\end{array}$} & \multirow[b]{2}{*}{\begin{tabular}{|r|}
\multicolumn{1}{|c}{$\%$} \\
51.8 \\
11.7 \\
10.3 \\
2.6 \\
13.3 \\
3.2 \\
1.4 \\
5.7
\end{tabular}} \\
\hline $\begin{array}{c}\text { All negativ } \\
\text { Positive on } \\
\text { " } " \\
\text { Positive in" } \\
\text { ", ", } \\
\text { ", }\end{array}$ & $\begin{array}{l}\text { ives .. } \\
\text { nly in nose } \\
\text { ", throat } \\
\text { ", nose perineum } \\
\text { ", nose and peroat } \\
\text {, throat and perin } \\
\text {, nose, throat, and }\end{array}$ & $\begin{array}{l}\because \\
\because \\
\cdots \\
a \\
\text { eum } \\
\text { neum perine } \\
\text { d per }\end{array}$ & 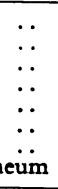 & $\begin{array}{l}. \\
\because \\
\because \\
\because \\
\because \\
.\end{array}$ & $\begin{array}{l}. . \\
\because \\
\because \\
\because \\
\because\end{array}$ & $\begin{array}{l}\because \\
\because \\
\because \\
\because \\
\because \\
\therefore\end{array}$ & & \\
\hline Total & $\begin{array}{lll}1 & . & \\
\end{array}$ & $\ldots$ &.. & .. & .. & .. & 3,508 & $100 \cdot 0$ \\
\hline $\begin{array}{cc}\text { Positive no } \\
\#, \\
\#, \quad \text { pe }\end{array}$ & $\begin{array}{l}\text { Ose cultures } \\
\text { hroat cultures } \\
\text { erineum cultures }\end{array}$ & $\because$. & 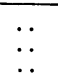 & $\because$ & $\because$ & $\because$ & $\begin{array}{r}1,190 \\
1,077 \\
449\end{array}$ & $\begin{array}{l}(33.9) \\
(30.7) \\
(12.8)\end{array}$ \\
\hline
\end{tabular}

Table II gives the distribution of the strains within the different phage groups. Of a total of 2,720 strains $13 \%$ were not typable. Of the strains isolated only from the perineum, $25 \%$ were not typable. Strains isolated by group I and III phages were in the majority.

Identical strains were isolated from $78 \%$ of the patients with positive nose and throat cultures, from $67 \%$ of those yielding positive nose and perineum cultures, from $48 \%$ of the patients who had staphylococci isolated only from the throat and perineum, and from $62 \%$ of those who had positive cultures from all three sites.

Of 449 perineal carriers of staphylococci, 224 were females and 225 males.

\section{Discussion}

The investigations reported show that perineal carriage of staphylococci is by no means rare. In this series $13 \%$ of the 
TABIE II.-Distribution of the Staphylococcal Strains Within the Different Phage Groups

\begin{tabular}{|c|c|c|c|c|c|c|c|c|}
\hline \multirow{2}{*}{$\begin{array}{c}\text { Site } \\
\text { of } \\
\text { Carriage }\end{array}$} & \multirow{2}{*}{$\begin{array}{c}\text { No. } \\
\text { of } \\
\text { Strains }\end{array}$} & \multicolumn{6}{|c|}{ Phage Groups } & \multirow{2}{*}{$\begin{array}{c}\text { Not } \\
\text { Typable } \\
\text { Strains }\end{array}$} \\
\hline & & I & II & III & IV & $\mathrm{V}$ & Misc. & \\
\hline $\begin{array}{l}\text { Pos. only } \\
\underset{\mathbf{T}}{\mathbf{P}} \\
\mathbf{P}\end{array}$ & $\begin{array}{r}412 \\
363 \\
90\end{array}$ & $\begin{array}{r}157 \\
106 \\
26\end{array}$ & $\begin{array}{r}50 \\
31 \\
9\end{array}$ & $\begin{array}{l}68 \\
78 \\
18\end{array}$ & $\begin{array}{r}1 \\
12 \\
0\end{array}$ & $\begin{array}{r}30 \\
11 \\
2\end{array}$ & $\begin{array}{l}49 \\
70 \\
12\end{array}$ & $\begin{array}{l}57 \\
55 \\
23 \\
\end{array}$ \\
\hline $\begin{array}{l}\text { Pos. N } \\
\text { and T }\end{array}$ & $\begin{array}{l}467 \\
470\end{array}$ & $\begin{array}{l}168 \\
162\end{array}$ & $\begin{array}{l}53 \\
57\end{array}$ & $\begin{array}{l}89 \\
90\end{array}$ & $\begin{array}{l}6 \\
7\end{array}$ & $\begin{array}{l}39 \\
25\end{array}$ & $\begin{array}{l}64 \\
81\end{array}$ & $\begin{array}{l}48 \\
48\end{array}$ \\
\hline $\begin{array}{l}\text { Pos. N } \\
\text { and } \mathbf{P}\end{array}$ & $\begin{array}{l}111 \\
111\end{array}$ & $\begin{array}{l}30 \\
26\end{array}$ & $\begin{array}{r}12 \\
8\end{array}$ & $\begin{array}{l}24 \\
24\end{array}$ & $\begin{array}{l}0 \\
1\end{array}$ & $\begin{array}{l}7 \\
4\end{array}$ & $\begin{array}{l}21 \\
24\end{array}$ & $\begin{array}{l}17 \\
24\end{array}$ \\
\hline $\begin{array}{l}\begin{array}{c}\text { Pos. } T \\
\text { and } P\end{array} \\
\end{array}$ & $\begin{array}{l}48 \\
48\end{array}$ & $\begin{array}{l}19 \\
12 \\
\end{array}$ & $\frac{1}{2}$ & $\begin{array}{r}8 \\
13 \\
\end{array}$ & $\begin{array}{l}1 \\
0\end{array}$ & $\begin{array}{l}4 \\
1 \\
\end{array}$ & $\begin{array}{r}11 \\
8 \\
\end{array}$ & 12 \\
\hline $\begin{array}{l}\text { Pos. } \mathrm{N} \\
\text { and } \mathrm{T} \\
\text { and } \mathrm{P}\end{array}$ & $\begin{array}{l}200 \\
200 \\
200\end{array}$ & $\begin{array}{l}59 \\
57 \\
54\end{array}$ & $\begin{array}{l}23 \\
20 \\
26\end{array}$ & $\begin{array}{l}43 \\
52 \\
46\end{array}$ & $\begin{array}{l}2 \\
2 \\
1\end{array}$ & $\begin{array}{r}13 \\
8 \\
7\end{array}$ & $\begin{array}{l}37 \\
36 \\
41\end{array}$ & $\begin{array}{l}23 \\
25 \\
25\end{array}$ \\
\hline Total $\left\{\begin{array}{l}\text { No. } \\
\%\end{array}\right.$ & $\begin{array}{r}2,720 \\
100\end{array}$ & $\begin{array}{c}876 \\
32 \cdot 2\end{array}$ & $\begin{array}{c}292 \\
10.7\end{array}$ & $\begin{array}{c}553 \\
20 \cdot 3\end{array}$ & $\begin{array}{c}33 \\
1.2\end{array}$ & $\begin{array}{c}151 \\
5.6\end{array}$ & $\begin{array}{c}454 \\
16 \cdot 7\end{array}$ & $\begin{array}{l}361 \\
13.3\end{array}$ \\
\hline
\end{tabular}

$\mathrm{N}=$ Nose. $\mathrm{T}=$ Throat. $\mathrm{P}=$ Perineum. Misc. $=$ Miscellaneous.

patients examined had pathogenic staphylococci isolated from their perineum, either in the perineum alone or most often combined with carriage in other sites.

Staphylococci are often isolated from the faeces (Buttiaux and Pierret, 1949 ; Martyn, 1949 ; Brodie et al., 1956 ; Matthias et al., 1957 ; Hofstad and Wormnes, 1961) and less often from the vagina (Buttiaux and Pierret, 1949). In the present investigation samples from the faeces and vagina were not obtained. The perineal area may probably in some cases have been contaminated by staphylococci from these sites. But the equal distribution of perineal carriers between the two sexes in this investigation suggests that contamination of the perineal area from the vagina was of minor importance.

Our figures must be regarded as minimum figures. Nearly all of the persons examined had had a bath within an hour before the perineal swabs were obtained. Ridley (1959) has shown that washing (more thoroughly in his investigation than an ordinary bath) reduces the number of staphylococci in the perineum. On account of his work it is suggested that staphylococci persisting in the perineum after washing should be present in fairly abundant numbers before washing, and accordingly the perineal area may be a real breeding-place for these organisms and a potential source of infection. A patient whose perineum is a breeding-place for staphylococci is probably more apt to contaminate his bedding than most of the nasal carriers, and by indirect routes he may represent a dangerous source of infection. Investigations by Ridley (1959) and Hare (1963) point in this direction. Studies of the quantitative aspects of staphylococcal carriage by one of us (Solberg, 1964) show that perineal carriers may be heavy dispersers of staphylococci, even heavier than most of the nasal carriers.

It is therefore likely that individuals, especially patients, who are perineal carriers of pathogenic staphylococci represent a relatively greater danger than one should suspect from the relatively low incidence of such carriers.

\section{Summary}

A total of 3,508 patients admitted to a medical department were examined for perineal carriage of pathogenic staphylococci: $13 \%$ had these organisms in the perineum, either in the perineum alone or combined with other sites, and $2.6 \%$ had staphylococci only in the perineum.

As patients with perineal carriage easily contaminate their bedclothes, they can more easily than other carriers become heavy dispersers. Perineal carriers may therefore be a greater problem in the handling of hospital infection than is expressed by their incidence. Quantitative studies to be reported point in this direction.

\section{REFERENCES}

Brodie, J., Kerr, M. R., and Sommerville, T. (1956). Lancet, 1, 19. Buttiaux, R., and Pierret, J. (1949). Ann. Inst. Pasteur, 76, 480.

Gillespie, W. A., Simpson, K., and Tozer, R. C. (1958). Lancet, 2, 1075. Hare, R (1963), In Infection in Hospitals, edited by R. E. O.'Williams and R. A. Shooter, p. 75. Blackwell, Oxford. and Ridley, M. (1958). Brit. med. Y., 1, 69.

Hofstad, T., and Vogelsang, Th.M. (1960). Acta path. microbiol. scand., 48,155 .

- and Wormnes, A. (1961). Ibid., 51, 275.

Martyn, G. (1949). Brit. med. 7., 1, 710 .

Matthias, J. Q., Shooter, R. A., and Williams, R. E. O. (1957). Lancet, 1,1172 .

Ridley, M. (1959). Brit. med. 7., 1, 270.

Solberg, C. O. (1964). In preparation.

Tulloch, L. G., Alder, V. G., and Gillespie, W. A. (1960). Brit. med. 7., 2,354 .

\title{
Treatment of Rheumatic Fever: Comparison of Effects of Aspirin and Phenylbutazone
}

\author{
G. WILL, M.B., CH.B., B.SC., M.R.C.P.ED., M.R.C.P.GLAS. ; W. R. MURDOCH, M.B., CH.B., M.R.C.P., M.R.C.P.ED., M.R.C.P.GLAS.
}

Recent advances in the management of rheumatic fever have been mainly in the field of prevention. Salicylates were the standard treatment until the introduction of steroid and A.C.T.H. therapy. The Joint Report of the M.R.C. and American Heart Association (1955) on the treatment of acute rheumatic fever in children failed, however, to demonstrate that either of these new treatments was superior to salicylates alone. The earlier favourite experience of one of us with phenylbutazone (Fleming and Will, 1953 ; Will, 1958) led us to make a fuller study comparing the effects of salicylates and phenylbutazone.

\section{Clinical Methods}

This series comprises 88 patients investigated and treated by one or both of us in the following hospitals: Glasgow Royal Infirmary ; Eastern District Hospital, Glasgow ; Greenock Royal Infirmary ; and Dumfries and Galloway Royal Infirmary. All cases fulfilled the modified Ducket Jones (1944) diagnostic criteria used in the Joint Report of the M.R.C. and American Heart Association (1955). In every case the E.S.R., E.C.G., $x$-ray examination of chest, throat swabs, and antistreptolysin $\mathrm{O}$ (ASO) titres were carried out routinely. The E.S.R. was 